From the Department of Pharmacology and Toxicology, College of Veterinary Medicine, Helsinki, and the Department of Virology, University of Helsinki, Helsinki, Finland.

\title{
Activation of Plasmin in Mastitic Milk
}

\author{
By Liisa Kaartinen, Eeva-Marjatta Salonen, Antti Vaheri and Markus Sandholm
}

\begin{abstract}
Kaartinen, L., E.-M. Salonen A. Vaheri and M. Sandholm: Activation of plasmin in mastitic milk. Acta vet. scand. 1988, 29, 485-491. - Milk and whey samples from healthy and inflamed udder quarters of 10 Ayrshire cows were analyzed for proteolytic activity using radial caseolysis procedures, a fluorogenic coumaryl peptide substrate, and casein agarose zymography. Free lysosomal enzyme activity ( $\mathrm{N}$-acetyl-beta-D-glucosaminidase) was used as the criterion for inflammation. All mastitic milk samples had proteolytic activity, tentatively identified as plasmin (comigration at $\mathrm{M}_{\mathrm{r}} 83000$ and characteristic fragmentation). The plasmin activities in mastitic milk were on average $2.9 \mu \mathrm{g} / \mathrm{ml}$ (range $0.5-12.5$ ) as measured by radial caseolysis. Milk or whey specimens from healthy quarters were all negative except 1 in which an activity of $0.1 \mu \mathrm{g} / \mathrm{ml}$ was found in both specimens. The caseolytic activities were totally inhibited by $50 \mathrm{KIU} / \mathrm{ml}$ of aprotinin, a serine proteinase inhibitor from bovine lung. No free plasminogen activator (PA) activity was found in any of the samples. Howewer, according to zymographic analyses PA molecules corresponding to urokinase were found in healthy and especially in mastitic specimens. Analysis of plasmin may provide an alternative means of screening for mastitic milk samples.
\end{abstract}

caseinolysis; plasminogen activator; bovine mastitis.

\section{Introduction}

Plasminogen activation is by far the most important mechanism of extracellular proteolysis and is involved in various tissue destructive processes, including inflammation and malignant cell invision (Danø et al. 1985). Plasminogen activation is a cascadelike process, regulated at several levels. Cells synthesize plasminogen activators as inactive proenzymes; these can be activated in vitro by minute amounts of plasmin to active two-chain forms. This mechanisms of activation is, however, unlikely to be the natural one since it would require the end product of the cascade, plasmin to be present for the first step of regulation. The 2 types of activators, urokinase-type (u-PA) and tissuetype (t-PA), have powerful inhibitors
(Sprengers \& Kluft 1985), of which already 4 different types have been characterized. These include PAI-1 (previously known as endothelial inhibitor $\mathrm{M}_{\mathrm{r}} 52 \mathrm{~K}$ ), PAI-2 (placental or monocyte/macrophage-derived inhibitor), PAI-3 (present in urine) and protease nexin which is not a specific PA inhibitor but also inhibits thrombin and plas$\min$.

The only well characterized substrate for both u-PA and t-PA is plasminogen, a proenzyme widely distributed in practically all body fluids and tissues. PA converts plasminogen to active plasmin, a serine proteinase with a broad spectrum of target proteins. These include not only fibrin and fibronectin but also certain latent enzymes, such as interstitial and basement membrane procol- 
lagenases and latent macrophage elastase, involved in degradation of tissue matrices. Thus, activation of plasminogen can trigger a set of enzyme leading to complete tissue matrix destruction (Danø et al. 1985, Blasi 1988). Plasmin, too, has powerful inhibitors present in body fluids (Travis \& Salvesen 1983). Of these the most important ones are the fast-acting alpha-2-antiplasmin and the wide-spectrum inhibitor alpha-2-macroglobulin. The phenomena in which plasminogen activation is known to be involved include fibrinolysis, cell migration, tissue remodeling, tissue involution such as occurs in the mammary gland when a lactating mouse is weaned from the litter or in cows at drying off, ovulation, trophoblastic invasion, and malignant transformation and cell invasion. Most of these processes involve u-PA, with the exception of fibrinolysis, in which t-PA is of critical importance.

In previous studies plasminogen activator has been found to be associated with bovine milk casein micelles, and a PA inhibitor (PAI) and plasmin in milk whey (KoryckaDahl et al. 1983). Detection of plasmin was based on the use of a chromogenic tripeptide substrate and on dissociation of the activity from the micelles using e-aminocaproid acid (eACA). Similarly, autoproteolysis of freshly isolated whole bovine casein has been attributed to bovine plasmin activity in milk (Eigel et al. 1979).

Mastitic milk has been recognized as a major problem in the dairy industry, responsible for lower cheese yields. This is partly due to degradation of casein by proteolysis (Kitchen 1981). In mastitis, rapid hydrolysis of milk casein by several different proteinases, including one with an electrophoretic band pattern resembling that of plasmin, has been reported (Andrews 1983). In a previous study we reported that the level of plasminlike activity released from casein micelles using trisodium citrate and assayed using a fluorogenic peptide substrate, correlated with the inflammatory level of subclinical mastitis, as well as with the in vitro growth of S. aureus and E. coli (Mattila et al. 1986). We also demonstrated that milk from inflamed quarters of mastitic udder required a smaller amount of urokinase to activate the fibrinolytic and caseolytic systems than milk from control quarters of the same cows (Kaartinen \& Sandholm 1987). We now report that active plasmin, identified using zymography, is regularly detected in milk from inflamed quarters but not in milk from adjacent healthy control quarters of the same cows.

\section{Materials and methods \\ Milk samples}

Ten Ayrshire cows at their mid-lactation and with evidence of subclinical mastitis were selected for the study. Milk was collected from the inflamed and the contralateral healthy quarter. The quarter was deemed to be unflamed if its $\mathrm{N}$-acetyl-beta-D-glucosaminidase (NAGase) activity exceeded that of the lowest quarter value by a factor of 4 or more. Only inflammation-positive samples with negative bacterial isolation were included in the study to avoid effects of bacterial proteinases. Both whole milk and whey were used in the subsequent analyses. After sampling the specimens were stored at $-20^{\circ}$ and analyzed within one week. The protein contents were determined using the BCA protein assay (Pierce, Rockford, IL).

\section{$N$-acetyl-beta-D-glucosaminidase}

The milk NAGase Test (Labsystems, Helsinki, Finland) (Mattila et al. 1986), which was used, is a microplate modification of the fluorogenic method of Kitchen (1978). The substrate, $50 \mu \mathrm{l}$ of $1,8 \mathrm{~mol} / \mathrm{l} 4$-methylumbelliferyl-N-acetyl-beta-D-glucosamin- 
ide, was mixed with $10 \mu \mathrm{l}$ milk at $\mathrm{pH} 4.6$, incubated at $22^{\circ} \mathrm{C}$ for $15 \mathrm{~min}$ and the reaction stopped by raising the $\mathrm{pH}$ to 10.5 with $100 \mu \mathrm{l}$ of $0.2 \mathrm{~mol} / \mathrm{l}$ glycine- $\mathrm{NaOH}, \mathrm{pH} 10.7$. The resulting fluorescence was measured by a microplate fluorometer (Fluoroskan, Labsystems), using an excitation wavelength of $355 \mathrm{~nm}$ and measurement of emission at $480 \mathrm{~nm}$.

\section{Protease assays}

Proteolytic activity in milk and whey was measured by 2 methods: by radial diffusion enzyme method in agarose gels containing casein, and by monitoring hydrolysis of a plasmin-specific fluorogenic coumaryl peptide substrate. Net proteolytic activity was determined using a modification of the radial caseinolysis procedure (Saksela 1981), described in detail elsewhere (Salonen et al. 1987). Briefly, $5 \mu$ l specimens were added to wells in an agarose gel containing bovine milk casein. Purified human plasmin (25 casein units/mg; Kabi Diagnostica, Stockholm, Sweden) was used as a standard. The diameters of the lytic zones in the caseincontaining gel were measured after incubation at $+37^{\circ} \mathrm{C}$ for $48 \mathrm{~h}$. The detection level of the assay was $0.1 \mu \mathrm{g} / \mathrm{ml}$. Aprotinin (Trasy$\mathrm{lol}^{\mathrm{R}}$, Bayer, Leverkusen, FRG) was tested as an inhibitor of the proteolytic activity. Plasminogen activator levels were determined according to Saksela (1981) using plasminogen-containing casein-agarose gels and purified human urokinase $(50000$ Ploug units/mg; Calbiochem, La Jolla, CA) as standard.

The fluorogenic assay was carried out as described by Richardson \& Pearce (1981) but on a microscale on microtitration plates (Mattila et al. 1986). $300 \mu \mathrm{l}$ of milk was mixed with $100 \mu \mathrm{l}$ of $0.4 \mathrm{~mol} / \mathrm{l}$ trisodium citrate to dissociate the casein micelles and to release the casein-bound plasmin. The samples were centrifugated at $10000 \times \mathrm{g}$ for $2 \mathrm{~min}$ and the fat was removed. A $20 \mu \mathrm{l}$ aliquot was mixed with $220 \mu \mathrm{l}$ of $0.05 \mathrm{~mol} / \mathrm{l}$ Tris-HCl buffer ( $\mathrm{pH}$ 7.4) on flat-bottom microtitration plates. To start the indicator reaction, $60 \mu \mathrm{l}$ of the substrate solution (1 mmol/1 N-succinyl-L-alanyl-L-phenylalanyl-L-lysyl-6-amino-4-methylcoumarine; Cambridge Research Chemicals, Harston, UK) was added. The substrate was dissolved in the Tris- $\mathrm{HCl}$ buffer containing $20 \%$ dimethyl sulphoxide by volume. The fluorescence was measured by a Fluroskan fluorometer (Labsystems) immediately after adding the substrate as well after $30 \mathrm{~min}$ at $25^{\circ}$ (excitation $355 \mathrm{~nm}$, emission $480 \mathrm{~nm}$ ). To convert the readings into units $(\mathrm{pmol} / \mathrm{min} /$ $\mathrm{ml}$ milk), the increase in fluorescence was compared with the fluorescence of standard solution of the hydrolytic product $(1 \mu \mathrm{mol} / 1$ 7-amino-4-methylcoumarine; Sigma, St. Louis, MO).

\section{Sodium dodecyl sulfate-polyacrylamide gel electrophoresis (SDS-PAGE) and zymo- graphy}

SDS-PAGE was performed on slab gels according to Laemmli (1970). The acrylamide concentration was $3.3 \%$ in the stacking gel and $5-16 \%$ in the separating gel. The samples were reduced with $4 \%$ (v/v) 2-mercaptoethanol in Laemmli's sample buffer. After electrophoresis the gels were stained with Coomassie Brilliant Blue R-250 for protein staining. Commercially available low molecular weight markers (Pharmacia, Uppsala, Sweden) supplemented with reduced fibronectin subunits $\left(\mathrm{M}_{\mathrm{r}}\right.$ 250000 ) were used.

Molecular weights of proteinases estimated using zymography (Granelli-Piperno \& Reich 1978), which consisted of SDS-PAGE under nonreducing conditions, followed by extensive washing of the gel with nonionic 
detergent and overlaying it with an indicator of casein-agarose, either with plasminogen (to detect PA) or without (to detect other casein-digesting proteinases). The lytic zones in the indicator gel layer developed within $24-48 \mathrm{~h}$ of incubation at $+37^{\circ} \mathrm{C}$.

\section{Results}

For the comparison of the proteolytic activities between the milk and whey specimens from healthy and mastitic quarters of the same udder we first determined the total protein contents. The following values were obtained for the different groups, consisting of 10 specimens each:

healthy milk $31.4 \mathrm{mg} / \mathrm{ml}$ (range 23.6-37.0) mastitic milk $31.4 \mathrm{mg} / \mathrm{ml}$ (range 18.2-40.0) healthy whey $17.0 \mathrm{mg} / \mathrm{ml}$ (range 12.1-24.8) mastitic whey $20.3 \mathrm{mg} / \mathrm{ml}$ (range 14.9-32.8) Thus no significant differences were found in the total protein contents between healthy and mastitic specimens. In the protease as- says $5 \mu$ l aliquots were used in the net proteolytic and PA assays, using the radial caseinolysis procedures described in Materials and methods.

As seen in Table 1, all milk and whey specimens from mastitic quarters were positive for proteinase activity. In the radial diffusion enzyme assay, plasmin was used as standard; the mean values were, for mastitic milk, 2.9 $\mu \mathrm{g} / \mathrm{ml}$ (range 0.5-12.5) and for mastitic whey, $2.7 \mu \mathrm{g} / \mathrm{ml}$ (range $0.5-12.5$ ). Milk or whey specimens from healthy quarters were all negative $(<0.1 \mu \mathrm{g} / \mathrm{ml})$ except one (patient no 3 in Table 1) in which an activity of $0.1 \mu \mathrm{g} / \mathrm{ml}$ was found in both specimens. Aprotinin, a known inhibitor of plasmin and other serine proteinases, totally inhibited the caseinolytic activities in the milk specimens at a concentration of $50 \mathrm{KIU} / \mathrm{ml}$.

The flurogenic assay gave similar results (Table 1). However, the difference between mastitic and control quarters was relatively

Table 1. N-acetyl-beta-D-glucosaminidase (NAGase), protease, and plasminogen activator activity (PA) in milk and whey from cows with mastitis. Protease activities were measured in parallel using a method based on hydrolysis of a fluorogenic peptide substrate and another method based on radial caseinolysis in agarose. $\mathrm{M}=$ mastitic quarter, $\mathrm{H}=$ healthy control quarter of the same cow.

\begin{tabular}{|c|c|c|c|c|c|c|c|c|c|c|c|c|}
\hline \multirow[t]{4}{*}{ Cow } & \multicolumn{2}{|c|}{$\begin{array}{l}\text { NAGase } \\
\text { (units/ml) }\end{array}$} & \multicolumn{6}{|c|}{ Proteolytic activity } & \multicolumn{4}{|c|}{$\begin{array}{l}\text { PA activity* } \\
\text { (PU/ml) }\end{array}$} \\
\hline & \multirow{2}{*}{\multicolumn{2}{|c|}{ Milk }} & \multicolumn{4}{|c|}{$\begin{array}{l}\text { Radial caseinolysis } \\
\mu \mathrm{g} / \mathrm{ml} \text { (ref. plasmin) }\end{array}$} & \multirow{2}{*}{\multicolumn{2}{|c|}{ 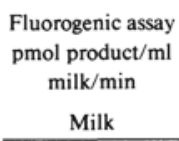 }} & \multirow{2}{*}{\multicolumn{2}{|c|}{ Milk }} & \multirow{2}{*}{\multicolumn{2}{|c|}{ Whey }} \\
\hline & & & \multicolumn{2}{|c|}{ Milk } & \multicolumn{2}{|c|}{ Whey } & & & & & & \\
\hline & M & H & M & $\mathrm{H}$ & M & $\mathrm{H}$ & $\mathrm{M}$ & H & $\mathrm{M}$ & $\mathrm{H}$ & $\mathrm{M}$ & $\mathrm{H}$ \\
\hline 1 & 68.9 & 9.8 & 1.3 & $<0.1$ & 0.7 & $<0.1$ & 80 & 77 & - & - & - & - \\
\hline 2 & 125.7 & 11.9 & 12.5 & $<0.1$ & 5.4 & $<0.1$ & 183 & 97 & - & - & - & - \\
\hline 3 & 18.1 & 4.1 & 0.5 & 0.1 & 1.0 & 0.1 & 155 & 114 & - & - & - & - \\
\hline 4 & 42.4 & 1.1 & 0.9 & $<0.1$ & 0.7 & $<0.1$ & 105 & 58 & - & - & - & - \\
\hline 5 & 57.2 & 2.1 & 0.8 & $<0.1$ & 0.8 & $<0.1$ & 116 & 62 & - & - & - & - \\
\hline 6 & 22.6 & 0.1 & 0.5 & $<0.1$ & 0.5 & $<0.1$ & 140 & 86 & - & - & - & - \\
\hline 7 & 57.8 & 0.1 & 0.8 & $<0.1$ & 1.6 & $<0.1$ & 138 & 45 & - & - & - & - \\
\hline 8 & 72.7 & 0.3 & 2.5 & $<0.1$ & 2.0 & $<0.1$ & 123 & 80 & - & - & - & - \\
\hline 9 & 84.4 & 8.4 & 8.3 & $<0.1$ & 12.5 & $<0.1$ & 181 & 108 & - & - & - & - \\
\hline 10 & 73.6 & 0.1 & 1.0 & $<0.1$ & 1.3 & $<0.1$ & 110 & 67 & - & - & - & - \\
\hline
\end{tabular}

* - PA activities were below the sensitivity range of the assay. 
smaller than the qualitative difference obtained with the radial caseinolysis procedure. All specimens, indicating those from mastitic and healthy quarters, were negative for plasminogen activator activity $(<1.0$ Ploug units/ml).

To characterize the proteinase molecules in mastitic milk and whey, zymography was performed after SDS-PAGE. The activity (Fig. 1) comigrated with human urokinase or with purified human plasmin standard. As shown in the zymographic analysis, when equal amounts of specimens were applied, a striking difference was seen between the specimens from healthy and mastitic udder quarters. In the zymography for non-PA proteinases (Fig. $1 \mathrm{~A}$ ) the mastitic specimens all showed the main activity comigrating with the plasmin standard $\left(M_{r} 82000\right)$. In addition, some activity was consistently seen at $M_{r} 55000$. This lower molecular weight band comigrated with a fragment, presumably generated by autodigestion, which we also found in commercial preparations of bovine plasmin. The specimens from healthy quarters contained considerably less activity, especially at the $M_{r} 82000$ region.

The zymograms for PA activity of the specimens were complicated by the presence of plasmin in the same specimens. In the zymograms (Fig. 1 B) the upper major band of $M_{r} 53000$ represents a summation of that due to "miniplasmin" and any intact urokinase present. Comparison of Figs. $1 \mathrm{~A}$ and B suggests that both healthy and mastitic specimens contains PA activity in this molecular weight region. The lower molecular weight band at $M_{r} 36000$, known as an active degradation product of urokinase generated by plasmin (Barlow et al. 1981), was highly increased in mastitic specimens when compared to the corresponding healthy samples. This indicated that plasminogen activator, corresponding to urokinase, was increased in mastitic milk and whey.

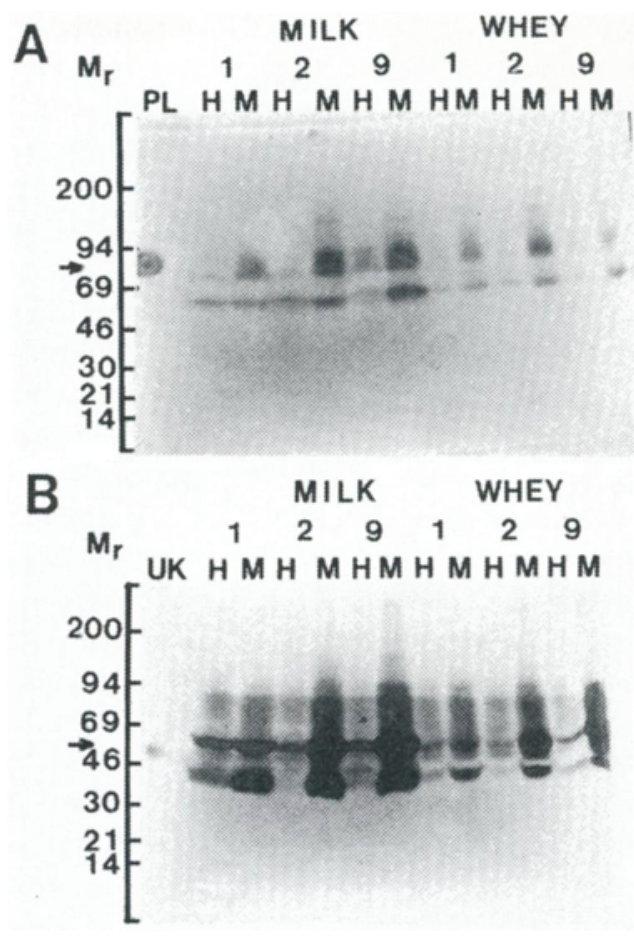

Figure 1. Casein-agarose zymography after SDSPAGE of milk and whey specimens from healthy $(\mathrm{H})$ and mastitic $(\mathrm{M})$ quarters of udders. The numbers refer to the cows listed in Table 1. The top figure (A) shows non-PA proteinases and the lower figure (B) zymography of plasminogen activators. Note that in the latter analysis also non-PA proteinases lyse the casein. The molecular weight markers $\left(\mathrm{M}_{\mathrm{r}}\right)$ in kilodaltons are indicated on the left. The arrows in A and B show the positions of plasmin (PL) and urokinase (UK), respectively.

\section{Discussion}

Previous reports have provided some evidence that plasmin activation can occur in milk, and that such activation is more pronounced in mastitis (Kaartinen \& Sandholm 1987). The present results confirm and extend these findings. We detected direct proteolytic activity in milk and whey specimens of all mastitic udder quarters, and practic- 
ally no activity in the milk of adjacent healthy quarters. This activity was tentatively identified as plasmin by the following criteria: comigration of the main activity in zymography with plasmin standard, and characteristic fragmentation to a protease molecule comigrating with an autodigested commercial bovine plasmin. The total inhibition of the proteolytic activity by aprotinin is also in agreement with plasmin being the major proteinase in mastitic milk. It should be noted, however, that our evidence for the proteinase being plasmin does not exclude the possibility that other proteinases (e.g. which are denatured in zymography, or which comigrate with plasmin or with its proteolytically digested lower molecular weight form) are present.

While in the radial caseinolysis assay a clear-cut qualitative difference was obtained between mastitic and healthy milk specimens, some proteolytic activity was also seen in the fluorogenic assay of healthy milk specimens. The basis for this apparent discrepancy is not known but we propose the following alternative explanations. In the radial caseinolysis procedure plasmin in the healthy milk specimens may be bound to casein micelles or proteinase inhibitors, and thus not be fully diffusible. Secondly, in the fluorogenic assay the small peptide substrate may be accessible even to bound plasmin, provided the active site of plasmin is free. Furthermore, the citrate pretreatment in the fluorogenic assay intended to release the complexed plasmin (Richardson \& Pearce 1981).

In zymography we detected PA activity corresponding to urokinase in healthy milk and especially in mastitic specimens (Fig. 1 B) but found no net PA activity in the radial caseinolysis assay (Table 1). We interpret these results to indicate that PA activity is dissociated from an inhibitor complex in the process of zymography. Moreover, it should be noted that activation of proenzyme to the active two-chain form of PA can occur during the zymography due to the plasminogen/plasmin in the overlay gel. In any event more PA was found in the specimens from mastitic than from healthy quarters of the udder.

This is not the first report on the detection of plasmin in body fluids in tissue destructive processes. We recently reported detection of plasmin in the human tear fluid in patients with corneal erosions and found that topical application of the plasmin-inhibitor aprotinin as eye drops to these patients provided a new successful therapy rapidly promoting corneal re-epithelialization (Salonen et al. 1987). It is notable that in many of these corneal ulcer patients there was no microbial involvement. These results from human patients suggested that an inflammatory process may proceed without microbial involvement to persistent tissue destruction and that in such cases therapeutic intervention with a plasmin inhibitor is successful. Whether this applies to mastitis is an interesting possibility.

Apart from the clinical status, the current diagnosis of mastitis is based on bacterial culture, and the count of inflammatory cells. Recently, NAGase as a measure of lysosomal enzymes was introduced as a reliable indicator for mastitis (Kitchen 1981). Our consistent detection of plasmin in mastitic milk may provide the basis for an alternative means of screen mastitic milk specimens.

\section{Acknowledgement}

We thank Dr. Ross W. Stephens for critical reading of the manuscript, Ms. Taija KyöstiöRenvall for expert technical assistance and the Sigrid Jusélius Foundation, Helsinki and the Medical Research Council of the Academy of Finland for financial support. 


\section{References}

Andrews AT: Breakdown of caseins by proteinases in bovine milks with high somatic cell counts arising from mastitis or infusion with bacterial endotoxin. J. Dairy Res. 1983, 50, $57-66$.

Barlow GH, Francis CW, Marder VT: On the conversion of high molecular weight urokinase to the low molecular weight form by plasmin. Thromb. Res. 1981, 23, 541-547.

Blasi F: Surface receptors for urokinase plasminogen activator. Fibrinolysis 1988 , in press.

Danø K, Andreasen PA, Grøndahl-Hansen J, Kristensen $P$, Nielsen LS, Skriver L: Plasminogen activators, tissue degradation and cancer. Adv. Cancer Res. 1985, 44, 139-266.

Eigel WN, Hofmann CJ, Chibber BAK, Tomich $J M$, Keenan TW, Mertz ET: Plasmin-mediated proteolysis of casein in bovine milk. Proc. Natl. Acad. Sci. USA 1979, 76, 2244 2248.

Granelli-Piperno A, Reich E: A study of proteases and protease-inhibitor complexes in biological fluids. J. exp. med. 1978, 146, 223-234.

Kaartinen L, Sandholm M: Regulation of plasmin activation in mastitic milk - Correlation with inflammatory markers and growth of Streptococcus agalactiae. J. Vet. Med. B. 1987, 34, 42-50.

Kitchen BJ: Review of the progress of dairy science: Bovine mastitis: compositional changes and related diagnostic tests. J. Dairy Res. 1981, 48, 167-188.

Korycka-Dahl M, Ribadeau Dumas B, Chene N, Martal J: Plasmin activity in milk. J. Dairy Sci. 1983, 66, 704-711.

Laemmli UK: Cleavage of structural proteins during the assembly of the head of bacteriophage T4. Nature (London) 1970, 227, 680-685.

Mattila T, Syväjärvi J, Sandholm M: Milk antitrypsin, NAGase, plasmin and bacterial replication rate in whey - effect of lactation stage, parity and daily milk yield. J. Vet. Med. B. 1986, 33, 462-470.
Richardson $B C$, Pearce $K N$ : The determination of plasmin in dairy products. New Zealand $\mathrm{J}$. Dairy Sci. Technol. 1981, 16, 209-220.

Saksela $O$ : Radial caseinolysis in agarose: a simple method for detection of plasminogen activator in the presence of inhibitory substances and serum. Anal. Biochem. 1981, 111, 276-282.

Salonen EM, Tervo T, Törmä E, Tarkkanen A, Vaheri A: Plasmin in tear fluid of patients with corneal ulcers: basis for new therapy. Acta Ophthalmol. 1987, 65, 3-12.

Sprengers ED, Kluft C: Plasminogen activator inhibitors. Blood 1987, 69, 381-387.

Travis J, Salvesen GS: Human plasma proteinase inhibitors. Ann. Rev. Biochem. 1983, 52, 655 -709 .

\section{Sammanfattning}

Plasmin aktivering i mastitmjölk.

Mjölk och mjölkserum prov från friska och inflammerade juverfjärdedelar från tio aushire kor analyserades beträffande proteolytisk aktivitet genom att använda en radial kaseinolysmetod, ett fluorgeniskt kumaryl peptid substrat och kasein agar zymatografi. Fri lysosomal aktivitet $(\mathrm{N}$-acetyl- $\beta$-D-glucosaminidase) användes som mått på inflammation. Alla mastitmjölk prov visade proteolytisk aktivitet, preliminärt identifierad som plasmin (komigration vid $\mathrm{M}_{\mathrm{r}} 83000$ och karakteristisk fragmentering. Plasmin aktiviteten i mastitmjölk var i medeltal $2,9 \mu \mathrm{g} / \mathrm{ml}$ (range $0,5-12,5$ ) med radial kaseinolys. Aktiviteten i mjölk och mjölkserum från friska juverfjärdedelar var negativ i alla utom ett prov, i vilken aktiviteten var 0,1 $\mu \mathrm{g} / \mathrm{ml}$ både i mjölk och mjölkserum. Den kaseinolytiska aktiviteten inhiberades totalt av 50 $\mathrm{KIU} / \mathrm{ml}$ aprotinin, en serin proteinas inhibitor från bovin lunga. Fri plasminogen aktivator (PA) aktivitet mättes inte $\mathrm{i}$ något av proven. Enligt zymografiska analyser hittades dock PA molekyler som motsvarar urokinas både i friska och särskilt i mastit mjölkprov. Analys av plasmin aktivitet kan vara en alternativ metod för undersökning av mastit mjölkprov.

(Received April 22, 1988).

Reprints may be requested from: Liisa Kaartinen, Department of Pharmacology and Toxicology, College of Veterinary Medicine, Hämeentie 57, SF-00550 Helsinki, Finland. 
